Józef Kus

\title{
„Lubliniana” w Narodowym Archiwum Historycznym Białorusi w Mińsku
}

Narodowe Archiwum Historyczne Białorusi w Mińsku [dalej: NAHB] przechowuje w swoim zasobie niezwykle bogate źródła do dziejów przedrozbiorowej Rzeczypospolitej, głównie Wielkiego Księstwa Litewskiego - księgi sądów szlacheckich: grodzkich (30 zespołów), ziemskich (67 zespołów), kapturowych (13 zespołów), podkomorskich (20 zespołów), kompromisarskich (10 zespołów), konfederackich (10 zespołów), a nadto akta miast (60 zespołów) i archiwa rodowe, z największym z nich na czele tj. Radziwiłłów, liczącym 25540 jednostek archiwalnych'. Obok nich, w znacznej ilości znaleźć można materiały wytworzone na terenie ziem koronnych: województwa podlaskiego ${ }^{2}$, lubelskiego, bełskiego i ziemi chełmskiej, a należące proweniencyjnie do zespołów ksiąg sądów szlacheckich i miejskich z okresu XV-XVII w., znajdujących się w archiwach polskich.

Archiwalia „koronne” (z wyjątkiem ksiąg podlaskich) przechowywane były do schyłku XIX w. w Lublinie w miejscowym Archiwum Akt Dawnych, utworzonym w 1827 r. ${ }^{3}$ Dla wszystkich zgromadzonych tu akt archiwista Piotr Zagrobski opracował „Konsygnację ogólną akt grodzkich, ziemskich, Trybunału Koronnego Lubelskiego, akt powiatów z całego województwa Lubelskiego w Lublinie skoncentrowanych...". W roku 1887 władze carskie uznały akta archiwum lubelskiego za dotyczące „ziem rosyjskich” i poleciły przekazać je do Archiwum Centralnego w Wilnie. Według protokółu sporządzonego wówczas przez ostatnich archiwistów AAD w Lublinie, Tomasza Zakrzewskiego i Feliksa Mazurkiewicza, wywieziono 4817 ksiąg ziemskich, grodzkich i miejskich i 76 przywilejów miejskich. W czasie I wojny światowej (w 1915 r.) zasób wileńskiego archiwum w znacznej części ewakuowano w głąb Rosji, te zaś akta, które pozostały w Wilnie, w 1919 r.

\footnotetext{
${ }^{1}$ Por. W. Kriegseisen, Źródła do historii Rzeczypospolitej szlacheckiej w Narodowym Archiwum Historycznym Białorusi w Mińsku, „Kwartalnik Historyczny”, t. 105, 1998, nr 4, s. 87-105.

${ }^{2}$ Informację o księgach grodzkich i ziemskich podlaskich w NAHB podaje M. Kulecki, zob. Pobyt stużbowy w Mińsku, „Archeion”, t. 93, 1994, s. 371-374.

${ }^{3}$ T. Mencel, Archiwum Akt Dawnych w Lublinie (1827-1887), ,Rocznik Lubelski”, t. 1, 1958, s. 7-36.
} 
powróciły do Lublina, chociaż nie wszystkie. Ogółem przywieziono wtedy 3518 ksiąg. ${ }^{4}$ Na powrót kolejnych ksiąg staropolskich przyszło czekać do 1961 r., kiedy to na mocy umowy o współpracy kulturalnej między PRL a ZSSR, zawartej w $1956 \mathrm{r}$. Archiwum Państwowe w Lubli nie odzyskało 406 ksiąg grodzkich i ziemskich lubelskich, chełmskich i horodelskich, grodzkich grabowieckich, ziemskich krasnostawskich i urzędowskich oraz podkomorskich lubelskich i chełmskich, a obok nich 51 ksiąg miejskich: lubelskich, kazimierskich, łęczyńskich, zamojskich i Trybunału Zamojskiego. ${ }^{5}$ Nadal jednakże część lubelskich archiwaliów staropolskich znajduje się po za granicami kraju, szacuje się ich ilość na około 200 j.a. ${ }^{6} \mathrm{Z}$ tej liczby ponad 50 j.a. znajduje się w Mińsku.

Podczas powojennej akcji rewindykacyjnej przechowywane były w Narodowym Archiwum Historycznym Białorusi w Grodnie, zaś do Mińska przewieziono je w $1964 \mathrm{r}$. Tu w następnych latach w większości sfoliowano je na nowo, poddano konserwacji i zmikrofilmowano. ${ }^{7}$

Rozpoznawaniem ksiąg sądów szlacheckich i miejskich z obszaru dawnych województwa lubelskiego i bełskiego oraz ziemi chełmskiej zajmowałem się podczas służbowego wyjazdu do Mińska w 2003 r.

W skład mińskich „Lublinianów” wchodzą (według przyjętej w NAHB numeracji i nazw zespołów):

Fond 1713, op.1 (Gorodlenskij Grodskij Sud) - Księgi grodzkie horodelskie z lat 1550-1698, 10 j.a.:

nr 1 - Zapisy (inscriptiones). Wpisy z lat 1603-1607. Księga /foliał/ liczy 460 kart, część kart miejscami nieczytelna. Poddana konserwacji, oprawiona i zmikrofilmowana w latach 1989-1990. Sygnatury dawne: „Nr 10”, grodzieńskaf. 1281, op.1, nr 1 .

nr 2 - Zapisy (inscriptiones). Wpisy z lat 1677-1698. Księga /foliał/ liczy 905 kart, część kart posiada drobne ubytki na brzegach. Poddana konserwacji, oprawiona i zmikrofilmowana w latach 1988-1989. Sygnatury dawne: grodzieńska - f. 1281, op.1, nr 2.

nr 3 - RMO (relationes, manifestationes, oblatae).Wpisy z lat 1677-1681; k. 578 uniwersał króla Jana III Sobieskiego w sprawie niebezpieczeństwa tureckiego

${ }^{4}$ J. Riabinin, Archiwum Państwowe w Lublinie, Warszawa 1926, s. 18-21.

${ }^{5}$ K. Wróbel-Lipowa, Rewindykacja archiwaliów polskich z ZSSR w latach 1945-1964, Lublin 1982, s. 111-114.

${ }_{6} 18$ ksiąg (5 grodzkich lubelskich, 5 grodzkich chełmskich, 3 ziemskie lubelskie, 1 ziemska krasnostawska, 2 podkomorskie lubelskie, 2 miejskie lubelskie i 1 miejska tyszowiecka) znajduje się w Rosyjskim Państwowym Archiwum Akt Dawnych w Moskwie, zaś 4 księgi (2 grodzkie lubelskie, 1 grodzka chełmska i 1 podkomorska lubelska) przechowywana jest w Archiwum Obwodu Jarosławlskiego w Jarosławlu. Zob. J. Łosowski, Staropolskie akta sąów szlacheckich i miejskich województw lubelskiego i betskiego oraz ziemi chetmskiej w archiwach Moskwy i Jarostawla, „Archeion”, t. 107, 2004, s. 363-376].

${ }^{7}$ Informacje z metryczek znajdujących się w księgach. 
(15 VI 1681 r.). Księga /foliał/ liczy 625 kart, na k. 1-35 ubytki tekstu. Poddana konserwacji, oprawiona i zmikrofilmowana w latach 1989-1990. Sygnatury dawne: grodzieńska - f. 1281, op.1, nr 3.

nr 4 - Zapisy (inscriptiones). Wpisy z lat 1624-1633. Księga/foliał/ liczy 551 kart, na k. 2, 4-11, 376-387, 507-519 znaczne ubytki. Poddana konserwacji, oprawiona i zmikrofilmowana w latach 1989-1990. Sygnatury dawne: „Nr 14”, grodzieńska - f. 1281, op.1, nr 4.

nr 5 - Wyroki (decreta). Wpisy z lat 1640-1647. Księga /foliał/ liczy 191 kart, na k. 15, 77-79, 122-123, 143-190 ślady wilgoci i znaczne ubytki. Poddana konserwacji, oprawiona i zmikrofilmowana w latach 1989-1990. Sygnatury dawne: „Nr 15”, grodzieńska - f. 1281, op.1, nr 5

nr 6 - Zapisy (inscriptiones). Wpisy z lat 1550-1571. Księga/foliał/ liczy 771 kart, na k. 1-40, 745-770 znaczne ubytki. Poddana konserwacji, oprawiona i zmikrofilmowana w roku 1989. Sygnatury dawne: „Nr 2”, grodzieńska - f. 1281, op.1, nr 6.

nr 7 - Zapisy (inscriptiones). Wpisy z lat 1658-1672. Tytuł oryginalny: Acta inscriptionum castrensi Horodliensi ab anno1658-1672”. Księga /foliał/ liczy 508 kart. Poddana konserwacji, oprawiona i zmikrofilmowana w latach 19891990. Sygnatury dawne: „Nr 36”, grodzieńska - f. 1281, op.1, nr 7.

nr 8 - Zapisy (inscriptiones). Wpisy z lat 1578-1583. Księga/foliał/ liczy 308 kart, na k. 3-25, 306-308 ślady wilgoci i nieznaczne ubytki. Poddana konserwacji, oprawiona i zmikrofilmowana w latach 1989-1990. Sygnatury dawne: „Nr 5”, grodzieńska - f. 1281, op.1, nr 8.

nr 9 - RMO (relationes, manifestationes, oblatae).Wpisy z lat 1690-1693. Oryginalny tytuł: $\mathrm{A}[\mathrm{cta}]$ relationum, protestationum, obductionum, oblatarum et aliorum susceptarum.... Księga /foliał/ liczy 661 kart. Poddana konserwacji, oprawiona i zmikrofilmowana w roku 1989. Sygnatury dawne: „38”, grodzieńska - f. 1281, op.1, nr 9.

nr 10 - RMO (relationes, manifestationes, oblatae).Wpisy z lat 1694-1698;((k. 31-33 testament Andrzeja Prusinowskiego, kasztelana lubaczowskiego i starosty horodelskiego (1694 r.), k. 390-393v - uniwersał prymasa Michała Stefana Radziejowskiego po śmierci króla Jana III Sobieskiego (27 VI 1696 r.). Księga /foliał/ liczy 717 kart. Poddana konserwacji, oprawiona i zmikrofilmowana w roku 1989. Sygnatury dawne: „40”(?), grodzieńska - f. 1281, op.1, nr 10.

Fond 1717,op.1 (Zamostskij Grodskij Sud) - nazwa mylna. W rzeczywistości jest to Trybunał Zamojski dla Miast Ordynacji Zamojskiej z lat 1634-1669, 2 j.a.:

nr 1 - [Acta Judiciis Generalibus Tribunalitiis Zamoscensis]. Wpisy z lat 1669-1674. Księga /foliał/ liczy 182 karty. Poddana konserwacji i oprawiona w 1978 r., zmikrofilmowana w 1979 r. Sygnatury dawne: - brak.

nr 2 - [Acta Judiciis Generalibus Tribunalitiis Zamoscensis]. Wpisy z lat 16341637. Księga /foliał/ liczy 172 karty. Stan fizyczny dobry, jednakże brak 
oprawy. Brak informacji o mikrofilmowaniu. Sygnatury dawne: grodzieńska - f. 1227, op. 1 nr. 1, poprzednia mińska - f. 1760, op. 1, nr 1 .

Fond 1720, op. 1 (Krasnostavskij Grodskij Sud) - nazwa mylna. W rzeczywistości są to:

nr 1 - Księga ziemska krasnostawska - Wyroki (decreta). Wpisy z roku 1590. Księga /dutka/ liczy 944 karty. Na k. 931-944 ubytek w górnym prawym rogu. Poddana konserwacji, oprawiona i zmikrofilmowana w roku 1978. Sygnatury dawne: „20”(?), grodzieńska - f. 1298, op. 1, nr.1.

nr 2 - ekstrakty z ksiąg grodzkich krasnostawskich, lwowskich i grabowieckich z lat 1623-1676. Kart luźnych 34. Sygnatury dawne: - brak.

Fond 1723, op.1 (Lukovskij Grodskij Sud) - nazwa mylna. W rzeczywistości jest to Księga podkomorska łukowska. Wpisy z lat 1536-1541. Księga /dutka/ liczy 302 karty. Na k. 1 - 41 ubytki na rogach, na k. 218 - 249 ubytki na dole. Poddana konserwacji, oprawiona i zmikrofilmowana w latach 1989-1990. Sygnatury dawne: grodzieńska - f. 1303, op.1, nr 1.

Fond 1740, op. 1 (Cholmskij Grodskij Sud) - Księgi grodzkie chełmskie z lat 1558-1680, 17 j.a.:

nr 1 - Zapisy (inscriptiones), także dekrety i relacje. Wpisy z lat 1558-1561. Księga /foliał/ liczy 372 karty. Stan fizyczny dobry. Oprawa z XIX w. /półskórek/, brak informacji o mikrofilmowaniu. Sygnatury dawne: „Księga 71” oraz „40”, grodzieńska - f. 1333, op.1, nr 1 .

nr 2 - jest to Księga ziemska chełmska Zapisy (inscriptiones). Wpisy z lat 15661576. Księga /dutka/ liczy 290 kart. Poddana konserwacji, oprawiona i zmikrofilmowana w 1978 r. Sygnatury dawne: „X”, grodzieńska - f. 1333, op.1, nr 9.

nr 3 - Zapisy (inscriptiones), także dekrety i relacje. Wpisy z lat 1576-1577. Księga /foliał/ liczy 240 kart. Tytuł oryginalny: „Acta capitaenalia castrensia Chelmensia tempore felicis regiminis generosi Alexandri Łaszcz...”. Stan fizyczny dobry. Oprawa oryginalna, skóra z tłoczeniami. Brak informacji o mikrofilmowaniu. Sygnatury dawne: „Księga 22” [skreślone 18] oraz „1088”, grodzieńska - f. 1333, op.1, nr 3.

nr 4 - Relacje(relationes), także manifestacje i oblaty /RMO/. Wpisy z lat 16201621. Księga /foliał/ liczy 808 kart. Stan fizyczny dobry. Oprawa oryginalna, skóra z tłoczeniami. Brak informacji o mikrofilmowaniu. Sygnatury dawne: „Księga 53” oraz „40”, grodzieńska - f. 1333, op.1, nr 4.

nr 5 - Wyroki (decreta), także relacje i manifestacje. Wpisy z lat 1633-1635. Księga /foliał/ liczy 578 kart. Stan fizyczny dobry. Oprawa z XX w., tektura, grzbiet płócienny. Brak informacji o mikrofilmowaniu. Sygnatury dawne: „74”, grodzieńska - f. 1333, op.1, nr 4. 


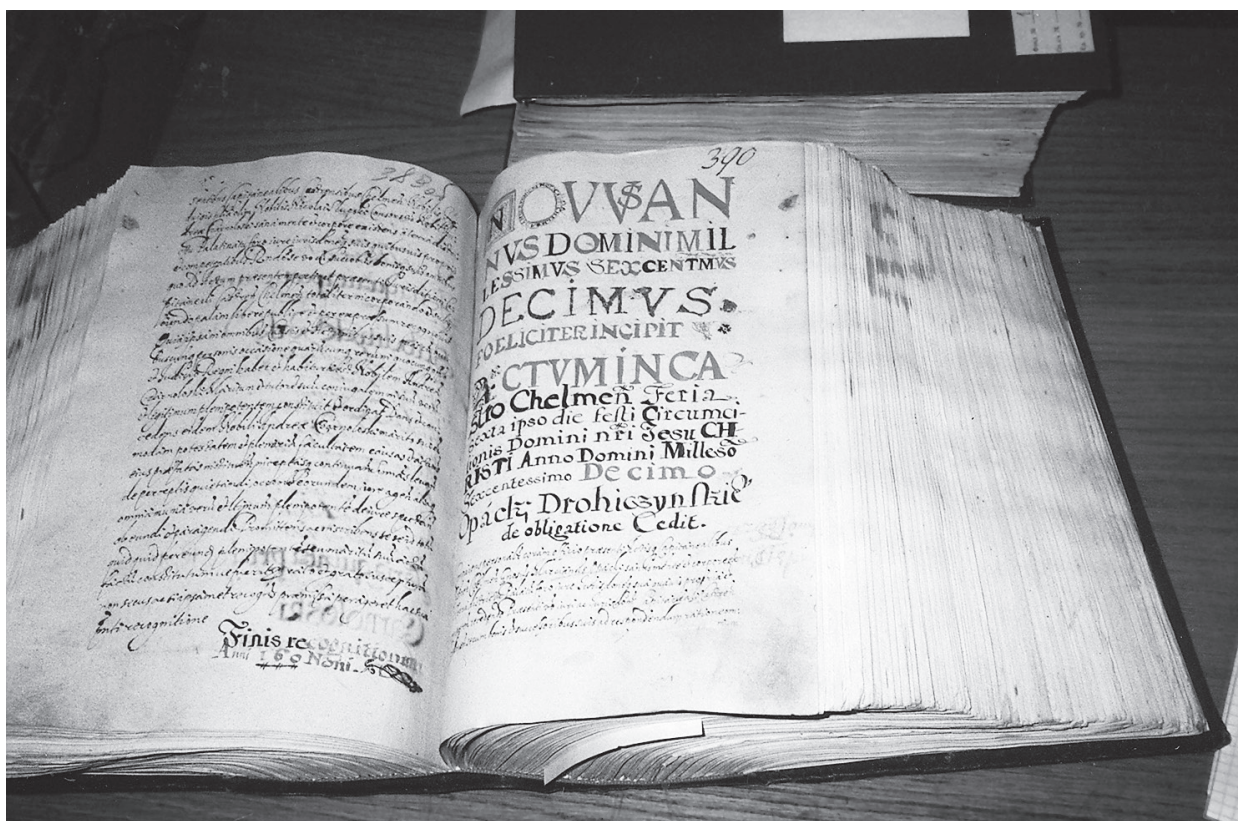

Księga grodzka chełmska przechowywana w Narodowym Archiwum Historycznym Białorusi w Mińsku

nr 6 - Relacje (relationes), także manifestacje i oblaty /RMO/. Wpisy z lat 16491650.; k. 432-438v - laudum $\mathrm{w}$ sprawie pospolitego ruszenia przeciwko Kozakom), k. 438v-440v - oblata kontraktu arendy czopowego, k. 440v452 - popis szlachty chełmskiej pod Zborowem. Księga /foliał/ liczy 1090 kart. Tytuł oryginalny: „Acta relationum castrensia Chelmensia tempore capiteanatus magnifici Joannis Thomae in Uhrowsko Krzywczycki ...". Stan fizyczny dobry. Oprawa zniszczona: deski i resztki skóry brak informacji o mikrofilmowaniu. Sygnatury dawne: „Księga 74” i „82”, grodzieńska f. 1333 , op.1, nr 6 .

nr 7 - Relacje (relationes), także manifestacje i oblaty /RMO/. Wpisy z roku 1669; k. 10v-11 - „Regestr pogorzenia domów rynkowych w miasteczku Wojsławiczach", k. 12v-13, 16-30v, 81v-82v, 104-107v, 165-168v,237-247, 311-313 lauda sejmikowe i instrukcje poselskie. Księga /foliał/ liczy 342 karty. Stan fizyczny dobry. Oprawa zniszczona: deski i resztki skóry, brak informacji o mikrofilmowaniu. Sygnatury dawne: „Księga 702” oraz „40” i „1365”, grodzieńska - f. 1333, op.1, nr 7

nr 8 - Relacje (relationes), także manifestacje i oblaty /RMO/. Wpisy z roku 1680. Księga /foliał/ liczy 756 kart. Stan fizyczny dobry, przygotowana do oprawy. Brak informacji o mikrofilmowaniu. Sygnatury dawne: grodzieńska f. 1333 , op.1, nr 8 . 
nr 9 - Relacje (relationes), także manifestacje i oblaty /RMO/. Wpisy z lat 1609-1610; k. 4-4v - uniwersał zakazujący zaciągu na służbę wojskową do „cudzych krajów” (1609 r.). Księga /foliał/ liczy 935 kart. Poddana konserwacji, oprawiona i zmikrofilmowana w 1978 r. Sygnatury dawne: „52”, grodzieńska f. 1333, op.1, nr 9 .

nr 10 - Relacje (relationes), także manifestacje i oblaty /RMO/. Wpisy z lat 16151616. Księga /foliał/ liczy 881 kart. Stan fizyczny dobry, brak jednakże oprawy. Brak informacji o mikrofilmowaniu. Sygnatury dawne: „58”, grodzieńska - f. 1333, op.1, nr 10.

nr 11 - Relacje (relationes), także manifestacje i oblaty/RMO/. Wpisy z roku 1636; k. 38, 492-498 - lauda sejmikowe i instrukcje poselskie. Księga /foliał/ liczy 510 kart. Poddana konserwacji, oprawiona i zmikrofilmowana w 1978 r. Sygnatury dawne: grodzieńska - f. 1333, op.1, nr 11.

nr 12 - Relacje (relationes), także manifestacje i oblaty /RMO/. Wpisy z lat 16371638. Księga /foliał/ liczy 819 kart. Stan fizyczny dobry. Oprawa oryginalna, skóra podniszczona. Brak informacji o mikrofilmowaniu. Sygnatury dawne: „Księga 64” i „71”, grodzieńska - f. 1333, op.1, nr 12.

nr 13 - Relacje (relationes), także manifestacje i oblaty /RMO/. Wpisy z 1663 r. Księga /foliał/ liczy 431 kart; do k. 25 znaczne ubytki. Poddana konserwacji, oprawiona i zmikrofilmowana w roku? Sygnatury dawne: „Xięga 8[?]”, grodzieńska - f. 1333, op.1, nr 13.

nr 14 - Relacje (relationes), także manifestacje i oblaty /RMO/. Wpisy z lat 16671668. Księga /foliał/ liczy 935 kart. Poddana konserwacji, oprawiona i zmikrofilmowana w 1978 r. Sygnatury dawne: „Księga 101”, grodzieńska f. 1333, op.1, nr 14 .

nr 15 - Relacje (relationes), także manifestacje i oblaty /RMO/. Wpisy z lat 1680, 1681. Księga /foliał/ liczy 45 kart, zachowana jest fragmentarycznie. Poddana konserwacji, oprawiona w 1978 r., zmikrofilmowana w 1979 r. Sygnatury dawne: grodzieńska - f. 1333, op.1, nr 15.

nr 16 - Relacje (relationes), także manifestacje i oblaty /RMO/. Wpisy z roku 1683. Księga /foliał/ liczy 256 kart. Zachowana jest fragmentarycznie i zaczyna się od dawnej k. 389. Poddana konserwacji i oprawiona w 1978 r., zmikrofilmowana w 1979 r. Sygnatury dawne: grodzieńska - f. 1333, op.1, nr 16.

nr 17 - Wyroki (decreta). Wpisy z lat 1603-1606. Księga /foliał/ liczy 942 karty. Tytuł oryginalny /wytłoczony na oprawie/: „ACTA CAP*CAST*CH*IVDICIO ET QUEERE*TEMPOREREGIMINISG*NICOLAIVROWIECKI*CAP*CVRA G*ADAMI RVDNICKI NOT*CASTR*CH*INTROLIGATA. Stan fizyczny dobry. Oprawa: skóra tłoczona. Brak informacji o mikrofilmowaniu. Sygnatury dawne: „N 20 286”, „39” i „49”, grodzieńska - f. 1333, op.1, nr 17.

nr 18 - Wyroki (decreta). Wpisy z lat 1626-1629. Księga /foliał/ liczy 1033 karty. Poddana konserwacji i oprawiona w 1978 r., zmikrofilmowana w 1979 r. Sygnatury dawne: - brak. 
Fond 1753, op.1 (Gorodlenskij Zemskij Sud) - Księgi ziemskie horodelskie z lat 1471-1602, 6 j.a.:

nr 1 - Wyroki (decreta). Wpisy z lat 1536-1562. Księga /foliał/ liczy 603 karty. Na kartach 261-277 ubytek w górnym prawym rogu. Poddana konserwacji, oprawiona i zmikrofilmowana w 1973 r. Sygnatury dawne: grodzieńska f. 1164, op.1, nr 11.

nr 2 - Wyroki (decreta). Wpisy z lat 1538-1584. Księga /dutka/ liczy 390 kart. Poddana konserwacji, oprawiona i zmikrofilmowana w 1973 r. Sygnatury dawne: „No 5”, ,ad Iudicium No 4”, „No 3”, ,, ad Iudicium No 3”, grodzieńska f. 1272 , op. 1 , nr 2 .

nr 3 - Wyroki (decreta). Wpisy z lat 1566-1579. Księga /dutka/ liczy 303 karty. Poddana konserwacji, oprawiona i zmikrofilmowana w 1973 r. Sygnatury dawne: grodzieńska - f. 1164, op. 1, nr 3.

nr 4 - Wyroki (decreta). Wpisy z lat 1471-1475, 1538-1561. Księga /dutka/ liczy 290 kart. Na kartach 50-52v wpis sądu ziemskiego w Chełmie z 1592 r. Karty 1-226 zniszczone od dołu do połowy wskutek dawnej wilgoci, widoczne ślady pleśni. Poddana konserwacji i oprawiona. Brak informacji o mikrofilmowaniu. Sygnatury dawne: „No 1”, ,, ad Iudicium No 1”.

nr 5 - Zapisy (inscriptiones). Wpisy z lat 1583-1596. Księga /foliał/ liczy 384 karty. Na k. 1-4 duże ubytki, na k. 5-37 niewielkie ubytki w dolnym zewnętrznym rogu. Poddana konserwacji i oprawiona. Brak informacji o mikrofilmowaniu. Sygnatury dawne: brak.

nr 6 - Zapisy (inscriptiones). Wpisy z lat 1597-1602. Księga /foliał/ liczy 619 kart. Na k. 1-20 niewielkie ubytki. Poddana konserwacji, oprawiona i zmikrofilmowana w 1973 r. Sygnatury dawne: brak.

Fond 1765, op.1 (Krasnostavskij Zemskij Sud) - Księgi ziemskie krasnostawskie z lat 1538-1596, 3 j.a.:

nr 1 - Zapisy (inscriptiones). Wpisy z lat 1538-1570. Księga /foliał/ liczy 669 kart. Stan fizyczny dość dobry. Nie podawana konserwacji, oprawa z XIX-XX w. Brak informacji o mikrofilmowaniu. Sygnatury dawne: grodzieńska f. 1207 , op. 1 , nr 1 .

nr 2 - Wyroki (decreta). Wpisy z lat 1562-1580. Księga /dutka/ liczy 924 karty. Poddana konserwacji i oprawiona w 1978 r., zmikrofilmowana w 1979 r. Sygnatury dawne: grodzieńska - f. 1207, op. 1, nr 2.

nr 3 - Zapisy (inscriptiones). Wpisy z lat 1553-1596. Księga /foliał/ liczy 261 kart. Poddana konserwacji i oprawiona w 1978 r., zmikrofilmowana w 1979 r. Sygnatury dawne: grodzieńska - f. 1207, op. 1, nr 3.

Fond 1768, op.1 (Ljublinskij Zemskij Sud) - Księgi ziemskie lubelskie z lat 15481623,12 j.a.: 
nr 1 - jest to Księga rachunkowa miasta Lublina - dochody i wydatki. Także rejestry poborowe szosu, pogłównego, podymnego, podatków na utrzymanie wojska. Wpisy z lat 1503-1550; s. 26 - 30v-rejestr poboru ,pro expeditione currum bellum” (1520 r.). Księga /dutka/ liczy 317 kart. Poddana konserwacji i oprawiona w NAHB. Sygnatury dawne: grodzieńska - f. 1301, op.1, nrl.

nr 2 - Zapisy (inscriptiones). Wpisy z lat 1548-1551. Księga/foliał/ liczy 359 kart. Na części kart /1 - 60/ ubytki. Poddana konserwacji i oprawiona w 1963 r., zmikrofilmowana w 1971 r.. Sygnatury dawne: grodzieńska - f. 1301, op.1, nr 2. nr 3 - Zapisy (inscriptiones). Wpisy z lat 1556-1558. Księga /foliał/ liczy 315 kart, na większości kart widoczne ślady wilgoci, w wielu miejscach tekst nieczytelny. Poddana konserwacji, oprawiona i zmikrofilmowana w 1973 r. Sygnatury dawne: grodzieńska - f. 1301, op.1, nr 3.

nr 4 - Zapisy (inscriptiones). Wpisy sądu sejmowego z roku 1556. Księga /foliał/ liczy 451 kart, na części kart nieznaczne ubytki. Poddana konserwacji i oprawiona w 1973 r. Sygnatury dawne: „Nr 33”, grodzieńska - f. 1301, op.1, nr 4. nr 5 - Zapisy (inscriptiones). Wpisy z lat 1568-1571. Księga /dutka/ liczy 403 karty. Poddana konserwacji, oprawiona i zmikrofilmowana w 1973 r. Sygnatury dawne: „26”, grodzieńska - f. 1301, op.1, nr 5.

nr 6 - jest to Księga ziemska urzędowska - Zapisy (inscriptiones). Wpisy z lat 15821592. Tytuł oryginalny: Acta controversiarum et protestationum”. Księga / dutka/ liczy 759 kart. Poddana konserwacji, oprawiona i zmikrofilmowana w 1973 r. Sygnatury dawne: grodzieńska - f. 1301, op.1, nr 6.

nr 7 - Zapisy (inscriptiones). Wpisy z lat 1586-1589. Tytuł oryginalny: Acta [...] sationum terrestria Lublinensia". Księga /foliał/ liczy 918 kart. Poddana konserwacji, oprawiona i zmikrofilmowana w 1973 r. Sygnatury dawne: grodzieńska - f. 1301, op.1, nr 7.

nr 8 - Zapisy (inscriptiones). Wpisy z lat 1586-1587, 1592. Księga /dutka/ liczy 797 kart. Poddana konserwacji, oprawiona i zmikrofilmowana w 1973 r. (?). Sygnatury dawne: grodzieńska - f. 1301, op.1, nr 8.

Nr 9 - Zapisy (inscriptiones). Wpisy z lat 1596-1597. Księga/dutka/ liczy 1413 kart. Poddana konserwacji, oprawiona i zmikrofilmowana w 1973 r. Sygnatury dawne: - brak.

nr 10 - jest to Księga ziemska urzędowska - Zapisy (inscriptiones). Wpisy z lat 1598-1599. Księga /dutka/ liczy 406 kart. Poddana konserwacji, oprawiona i zmikrofilmowana w 1973 r. Sygnatury dawne: grodzieńska - f. 1301, op.1, nr 10.

nr 11 - Zapisy (inscriptiones). Wpisy z lat 1613-1615. Księga /foliał/ liczy 782 karty. Poddana konserwacji, oprawiona i zmikrofilmowana w 1973 r. Sygnatury dawne: „60”, grodzieńska - f. 1301, op.1, nr 11.

nr 12 - jest to Księga wójtowsko-ławnicza miasta Lublina - Testamenty i inwentarze mieszczańskie. Tytuł oryginalny: „Acta testamentorum et inventariorum iudici civilis Lublinensi”. Wpisy z lat 1621-1626, m.in. s. 6v-12, 22-35-testament 
i inwentarz rajcy Jana Szulca (1621 r.), s. 339-376v - testamenty spisywane „tempore pestis grassantis” w 1625 r. przed domami zarażonych. Księga / dutka/ liczy 376 kart, część kart nieczytelna z ubytkami. Stan fizyczny dobry, nie była poddana konserwacji. Oprawa - skóra zdobiona; napis wytłoczony na okładce w większej części zaklejony papierową etykietką z tytułem księgi w jęz. rosyjskim, datami skrajnymi i dwoma pieczątkami archiwów w Grodnie i Mińsku; nad etykietką widoczne: ACTA, pod nią: ALBERTO LEWICKI NOTARIO. Na grzbiecie złocone litery: ACTA TESTAMENTORUM ANNORUM 1621, 1622, 1623, 1624, 1625, 1626. Sygnatury dawne: grodzieńska - f. 1301, op.1, nr 12.

Fond 1790, op.1 (Cholmskij Zemskij Sud) - Księgi ziemskie chełmskie z lat 14361596,6 j.a.:

nr 1 - Zapisy (inscriptiones). Wpisy z lat 1570-1579. Księga /dutka/ liczy 1117 kart. Znaczna część zbutwiała z ubytkami. Karty 1011-1014 - fragment księgi miejskiej Puchaczowa z 1671 r. Nie była poddana konserwacji, oprawy brak Sygnatury dawne: „Nr 23”, grodzieńska - f. 1332, op.1, nr 1. Z powodu złego stanu fizycznego nie jest udostępniana.

nr 2 - Zapisy (inscriptiones). Wpisy z lat 1471-1498. Księga /dutka/ liczy 395 kart. Znaczna część zbutwiała z ubytkami. Nie była poddana konserwacji, oprawa z XIX w. /półskórek/, zniszczona. Sygnatury dawne: - brak. Z powodu złego stanu fizycznego nie jest udostępniana.

nr 3 - Zapisy (inscriptiones). Wpisy z lat 1562-1563, 1574, 1583-1584. Księga /dutka/ liczy 1280 kart. Składki przemieszane chronologicznie. Nie była poddana konserwacji, oprawy brak Sygnatury dawne: „Nr 21”, grodzieńska - f. 1332, op.1, nr 3.

nr 4 - Zapisy i wyroki (inscriptiones, decreta). Wpisy z lat 1433, 1500-1533 z lukami chronologicznymi. Księga /dutka/ liczy 355 kart. Znaczna część zbutwiała, nieczytelna. Nie była poddana konserwacji. Oprawa z XIX w. /półskórek/, z naklejką na grzbiecie: ,Zapisy i wyroki Chełmskie 1436-1586”. Sygnatury dawne: grodzieńska - f. 1332, op.1, nr 4. Z powodu złego stanu fizycznego nie jest udostępniana.

nr 5 - Zapisy (inscriptiones). Wpisy z lat 1566-1577. Księga /foliał/ liczy 318 kart. Pierwsze 6 kart z ubytkami. Nie była poddana konserwacji. Oprawa z XIX w. /półskórek/. Sygnatury dawne: „Nr 9”, grodzieńska - f. 1332, op.1, nr 5.

nr 6 - Zapisy (inscriptiones). Wpisy z lat 1580-1586. Księga /dutka/ liczy 1074 karty. Znaczna część /do k. 370/ zbutwiała z ubytkami. Nie była poddana konserwacji. Oprawy brak, pozostał tyko grzbiet. Sygnatury dawne: „Nr 18”, grodzieńska - f. 1332, op.1, nr 6. Z powodu złego stanu fizycznego nie jest udostępniana.

nr 7 - jest to Księga ziemska krasnostawska - Zapisy (inscriptiones). Wpisy z lat 1584-1593. Księga /dutka/ liczy 591 kart. Pierwsza karta zdobna: „Acta sunt 
haec in Crasnistaw...”. Nie była poddana konserwacji. Oprawy brak. Sygnatury dawne: grodzieńska - f. 1332, op.1, nr 7.

Fond 1807, op.1 (Zamostskij Magistrat) - Akta miasta Zamościa (Armenica) z lat 1660-1668, 1 j.a.:

nr 1 - Księga wójtowsko-ławnicza prawa uprzywilejowanego ormiańskiego. Wpisy z lat 1660-1668. Księga /foliał/ liczy 258 kart i zaczyna się od k. 2. Stan fizyczny dobry, brak jednakże oprawy. Sygnatury dawne: - „Nro 4”, grodzieńska - f. 1351, op.1, nr 1 .

Fond 1815, op.1 (Ljublinskij Magistrat) - Akta miasta Lublina z lat 1534-1698, 10 j.a.:

nr 1 - Księga radziecka, indukta zawierająca sprawy sporne, niesporne, administracyjne. Wpisy z lat 1563-1569, 1578, 1571, od k. 455 chronologicznie przemieszane; s. 287v-288v - ugoda z Żydami z 1564 r., s. 445 - zapis o zarazie w 1565 r. Księga/foliał/ liczy 467 kart. Poddana konserwacji i oprawiona w NAHB. Sygnatury dawne: - brak.

nr 2 - Księga wójtowsko-ławnicza, indukta zawierająca sprawy sporne i niesporne. Wpisy z lat 1569-1571. Księga /foliał/ liczy 698 kart, zaczyna się od k. 2. Poddana konserwacji i oprawiona w NAHB. Sygnatury dawne: - brak.

nr 3 - Księga wójtowsko-ławnicza - Testamenty i inwentarze mieszczańskie. Wpisy z lat 1664-1676, m.in. k. 32-33 - inwentarz pozostałości po rajcy Jerzym Lemce (1666 r.), k. 34-38v - inwentarz i taksa pozostałości po rajcy Janie Autenlekt (1666 r.), k. 153-161 - testament i inwentarz Stanisława Kukro, pisarza radzieckiego (1667 r.). Księga /dutka/ liczy 259 kart, część kart nieczytelna z ubytkami. Poddana konserwacji i oprawiona w NAHB. Sygnatury dawne: - brak.

nr 4 - Księga radziecka, protocollon zawierająca sprawy sporne, niesporne, administracyjne. Wpisy z lat 1588-1591; Księga/foliał/ liczy 737 kart, od k. 315 znaczne ubytki. Poddana konserwacji i oprawiona w NAHB. Sygnatury dawne: - brak.

nr 5 - Księga radziecka, protocollon zawierająca sprawy sporne, niesporne, administracyjne. Wpisy z lat 1591-1593; k. 342v - mandat króla Zygmunta III / Warszawa, 27 XI 1592 r./zezwalający „,kupcom moskiewskim, którzy pod ten czas przy gońcu kniazia wielkiego moskiewskiego z towary swemi do państwa naszego przyjechali, a mianowicie Szyraiowi?, Iwanowiczowi, Kurszczenikowi w mieszcziech naszych, w których jarmarki zawołane bywają, zwłaszcza w Toruniu, Gdańsku, Poznaniu, Gnieźnie i Lublinie, przedawać i handlować...”. Księga/foliał/ liczy 348 kart, od k. 315 znaczne ubytki. Poddana konserwacji i oprawiona w NAHB. Sygnatury dawne: - brak.

nr 6 - Księga rachunkowa - dochody i wydatki. Także rejestry poborowe szosu, pogłównego, podymnego, podatków na utrzymanie wojska. Wpisy z lat 1585 
1654 to głównie wydatki, wpisy z lat 1655-1692 głównie rejestry podatkowe; m.in. k. 21-27v - rejestr wydatków na restaurację wieży kolegiaty lubelskiej po pożarze w 1653 r., k. 28-60 - składka w pieniądzach i kosztownościach na okup dla wojsk „Jego Carskiej Wieliczestwa” (1655 r.), k. 181-187v - składka „na harmatę i piechotę JKM”. Księga /foliał/ liczy 277 kart. Poddana konserwacji i oprawiona w NAHB. Sygnatury dawne: - brak.

nr 7 - Księga rachunkowa - dochody i wydatki. Także rejestry poborowe szosu, pogłównego, podymnego, podatków na utrzymanie wojska. Wpisy z lat 16531698; k. 59v - herb Lublina w kartuszu (1654 r.). Księga /foliał/ liczy 326 kart, do k. 42 znaczne ubytki. Poddana konserwacji i oprawiona w NAHB. Sygnatury dawne: - brak.

nr 8 - Księga dzierżaw kramów. Tytuł oryginalny: „Acta institarum coram Consulatu Lublinensi inscriptarum”. Wpisy z lat 1534-1604. Księga /dutka/ liczy 192 karty. Poddana konserwacji i oprawiona w NAHB. Sygnatury dawne: - brak. nr 9 - Księga dochodów jarmarcznych. Tytuł oryginalny: „Exactiones budnego et składnego etc.”. Wpisy z lat 1577-1626; k. 74v, 97v, 146, 148, 152, 157, 159v160 zapisy o charakterze kronikarskim. Księga /dutka/ liczy 368 kart, od k. 126 ubytki ku końcowi księgi coraz większe, od k. 348 sięgające 3/4 karty. Poddana konserwacji i oprawiona w NAHB. Sygnatury dawne: - brak.

nr 10 - Bifolium zatytułowane „Monialis Snopkowska a hortui BMV tratio” z 1622 r. z podpisem pisarza ziemskiego lubelskiego Sierakowskiego. Sygnatury dawne: - brak.

Ponadto w aktach Sądu Ziemskiego Drohickiego (Fond 1579) znajduje się 1 księga ziemska lubelska z lat 1416-1439 (nr 1a). Księgi tej jednakże nie udało mi się przejrzeć.

Inwentarze /maszynopisowe/ do zespołów akt sądów grodzkich posiadają identyczne wstępy, zawierające ogólne informacje o dziejach sądów grodzkich na Białorusi. Podobnie jest w przypadku sądów ziemskich. Nie inaczej zresztą potraktowane zostały wstępy do inwentarzy ksiąg miejskich. Dla autora (autorów?) tych wstępów nie było ważne, że województwa lubelskiego i ziemi chełmskiej nie można w żaden sposób zaliczyć do Wielkiego Księstwa Litewskiego ani Białorusi. 